\title{
The study of chemical composition of fatty oil from Carthamus lanatus (L.) Boiss. seeds
}

\author{
Shahla A. Gasimova \\ Institute of Botany, Azerbaijan National Academy of Sciences, \\ Badamdar 40, Baku, AZ1004, Azerbaijan
}

Abstract: This article presents the physicochemical properties, composition and content of seed oil, fatty acids of Carthamus lanatus (L.) Boiss. (Asteraceae Bercht. et J. Presl). This species is distributed in almost all botanical and geographical regions of Azerbaijan, growing from lowland to the lower mountain belt in meadows, summer pastures, neglected places, along roads and in gardens. The seeds of the plant were Shamakhi region. The qualitative composition and quantitative determination of fatty acid methyl esters were determined on an HP 6890 capilar column Agilent 112-88A7 series chromatograph with a flame ionization detector. As a result of study of the chemical composition of fatty oil from the seeds of Carthamus lanatus by gasliquid chromatography it was revealed that it contains eight fatty acids and trans-isomers. The main part of fatty acids is linoleic (75.2\%) and oleic acid (13.3\%). The rest accounted for palmitic $(6.6 \%)$, stearic $(3.5 \%)$, linolenic $(0.1 \%)$, eicosinic $(0.1 \%)$, palmitoleic $(0.1)$, myristic $(0,1 \%)$ acids and trans-isomers $(0.14 \%)$. It was determined that fatty oil has the following indicators: the saponification number is 192.1 , the amount of free fatty acids $-0.8 \%$, the peroxide number -2.1 , the iodine number - 142.5, the weight fraction of phosphoruscontaining substances $-3.0 \mathrm{mg} / \mathrm{kg}$. The high content of linoleic oil in the studied oil and a significant content of oleic acids, which are $\omega-6$ and $\omega-3$ unlimiting fatty acids, from a dietary point of view characterizes seed oil of $C$. lanatus as a valuable product. Considering the large natural reserves of $C$. lanatus in the flora of Azerbaijan, it can be confirmed that $C$. lanatus has quite good prospects for use as a medicinal, food and technical plant.

Key Words: Asteraceae, fatty oil plant, gas-liquid chromatography, fatty acids.

Accepted for publication: 15 May 2019

E-mail: sehla.qasimova.80@mail.ru

\section{INTRODUCTION}

Carthamus L. genus (the family Asteraceae Bercht. et J. Presl) is represented in the flora of Azerbaijan by five species: Carthamus lanatus (L.) Boiss., C. glaucus Bieb., C. oxycanthus Bieb., C. gypsicola Iljin, $C$. tinctorius $\mathrm{L}$. The most common of these species is $C$. lanatus (Saffron thistle), an annual cobwebby - pilose plant. The stem is $20-50 \mathrm{sm}$ tall, straight, corymboidbranched at the top, with few branches. Basal leaves pinnatisect, stem sessile, leather-like. The baskets at the ends of the branches are single, the flowers are yellow.

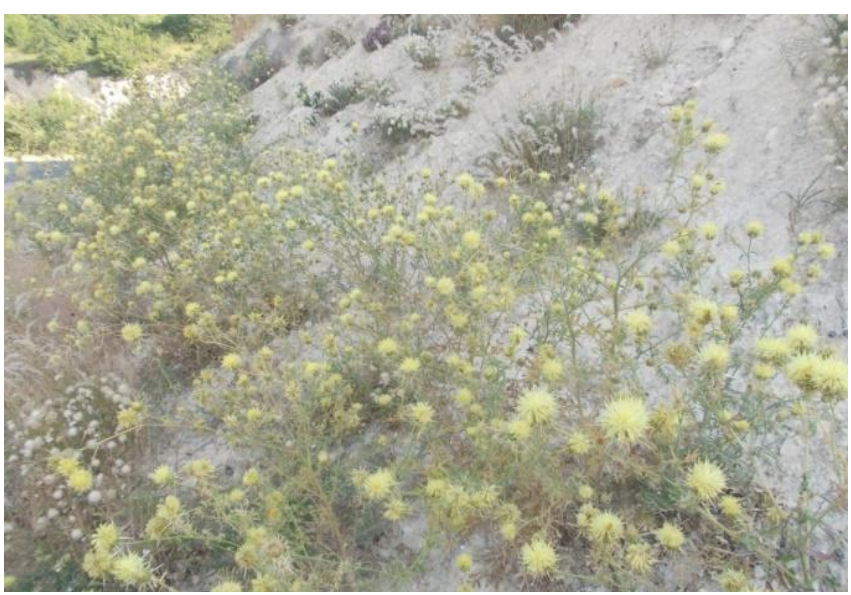

Figure 1. Carthamus lanatus (L.) Boiss.

Achenes are about $5 \mathrm{~mm}$ in length, tetrahedral, bare (Fig. 1).

Saffron thistle is distributed in almost all botanical and geographical regions of Azerbaijan, growing from lowland to the lower mountain zone in meadows, summer pastures, neglected places, along roads and in gardens [Flora Azerbaidjana, 1961].

In the above-ground parts of $C$. lanatus were found sesquiterpenoids (fucoside bisabolene, fucoside 3 -norbisabolene, intermedeol- $\beta$-D-fucopyranoside, 2 $\alpha$-methyl butyrate $\beta$-D- fucopyranoside intermedeol) and flavonoid luteolin and its derivatives (luteolin7-O-glucoside, luteolin-7-O-rutinozide and cruiser7-O-glucoside) [Feliciano et al., 1990a, b; El-Shaer et al., 1998]. Anthocyanins (cyanide-3-glycoside, cyanidin-3,5-diglucoside, pelargonidin -3-glucoside), flavonoids (isoquercitrin, quercitrin $3-\mathrm{O}-\alpha$-arabinoside 7-O-ß-glucoside, kempferol 3-O-ß-glucoside, luteolin 
7-O- $\beta$-glucoside, cartamidine 5 -O- $\beta$-glucoside and in seeds - flavonoids (apigenin, quercitrin and N- (p-methoxycinnamoyl) serotonin, mono ß-D-glucopyranoside) were recorded in flowers [Novruzov et al., 1998; Weiss, 1983; El-Shaer et al., 1998].

A.A. Kuliyev [1983] extracted fatty oil (26\%) with an iodine number of 124 from the seeds of $C$. lanatus collected in the Nakhchivan Autonomous Republic. Linoleic acid (76.7) and oleic acid (14.5) constituted the largest percentage of oil. E.A. Weiss [Weiss, 1983] obtained fatty oil of $16-20 \%$ with iodine number of 138 144 in the seeds of this plant. I.Y.L. Murthy and N.K. Anjani [2008] found oleic (23.2\%) and palmitic (9.7\%) acids in large quantities in fatty oil from the seeds of this plant collected in the Kashmir Valley, India.

In the aerial parts of $C$. lanatus aglycones, phenolic compounds (5-hydroxy-6,7-dimethoxyflavone and 5-hydroxy-7-methoxy-flavone) and flavonoid (chrysin) were detected using GC/MS [Mitova et al., 2003]. These compounds have anti-inflammatory, antitumor, antibacterial, antiviral, antifungal, antiulcer, antihepatotoxic and antioxidant activity [Pathak et al., 1991; Wassel et al., 1996; El-Shaer et al., 1998; Harborne et al., 1999; Kim et al., 1999; Morishita et al., 2001; Lee et al., 2002; Taskova et al., 2002].

Experimental studies of the methanol extract of the aerial parts $C$. lanatus revealed antimicrobial activity against gram-positive (Staphylococcus aureus, St. epidermidis and Bacillus subtilis) and gram-negative (Escherichia coli) bacteria, as well as mold fungi (Aspergillus niger, A. flavus and Alternaria solani). Activity against $A$. flavus is $100 \%$, against $A$. solani and A. niger is $90 \%$ [Sani et al., 2016]. In folk medicine, the infusion and decoction of leaves of $C$. lanatus is used as a diaphoretic, choleretic, diuretic, as well as for jaundice, sore throat and hysteria; fruits - laxative; the ashes of the aerial parts - antidote to scorpion bites. The leaves in cosmetics are used as blush, and also suitable for dyeing silk in orange-purple color. The plant is fodder for all animal species [Heller, 1986; Oomah et al., 1998]. Due to the relevant pharmaceutical and potential economic value of the plant species a field campaign was organized by the Institute of Botany of ANAS for collecting the seeds C. lanatus in several areas of Azerbaijan.

\section{MATERIAL AND METHODS}

The plant material for extracting fatty oil was collected in August 2016 on the outskirts of Angiharan of Shamakhi district (Azerbaijan) in the phase of full ripeness of seeds. Herbarium specimens of $C$. lanatus collected during expedition trips were delivered to the herbarium fund (BAK) of the Institute of Botany.

The seeds were dried in a thermostat (Binder FD (E2), Germany) at the temperature of $105^{\circ} \mathrm{C}$ to a residual moisture content of $2 \%$. Then the dried seeds were crushed and extracted with n-hexane. The extract was evaporated using an evaporator on a Soxhlet apparatus. The fatty oil yield was 33\%. The qualitative composition and quantitative content of fatty acid methyl esters were determined on an HP 6890 series chromatograph (HP 6890 Capilar column Agilent 112-88A7, Alltech, Poland) with a flame ionization detector.

A 100 meter long Agilent Techolgies 112-88A7 column was used for separation. The temperature mode of the column was programmed as follows: Initial temperature $140^{\circ} \mathrm{C}-5$ minutes of steady state, temperature rises of $4^{\circ} \mathrm{C} / \mathrm{min}$ to $240^{\circ} \mathrm{C}-15$ minutes steady state. The analysis process took $45 \mathrm{~min}$. The carrier gas was hydrogen, sample injection with flow division.

The preparation of sample for analysis was carried out according to State Standard (GOST 31663-2012). In a test tube with a capacity of $20 \mathrm{ml}$ weighed a portion of a fatty oil weighing $1 \mathrm{~g}$ and dissolved in $10 \mathrm{ml}$ of heptane. $0.5 \mathrm{ml}$ of a methanol solution of potassium hydroxide was pipetted to the resulting solution, the tube was capped and intensively shaken for 2 minutes. Following five minutes of settling, the upper layer was collected for gas chromatographic analysis.

The content of the components was calculated by the method of normalization over the areas of gas chromatographic peaks without using sensitivity coefficients. For the identification of fatty acid methyl esters, the Supelco 37 Component FAME Mix standard was used. Physicochemical and organoleptic indicators were determined by standard methods.

\section{RESULTS AND DISCUSSION}

The method of gas-liquid chromatographic analysis allows effectively carrying out the separation of fatty acid methyl esters at a lower temperature and a shorter duration of time. The result of gas chromatographic analyzes of oil fatty acids of C. lanatus is presented in Fig. 2.

The amount of individual fatty acids respect to the total amount is not the same, the content of individual components from the total amount of fatty acids varies from 0.1 to $75.2 \%$ as it can be seen from Fig. 3 . The composition of fatty acids (of the total amount) is dominated by linoleic $(75.2 \%)$ and oleic $(13.3 \%)$,which were the most abundant fatty acids, where as the rest of the fatty acids are accounted for palmitic (6.6\%), stearic 


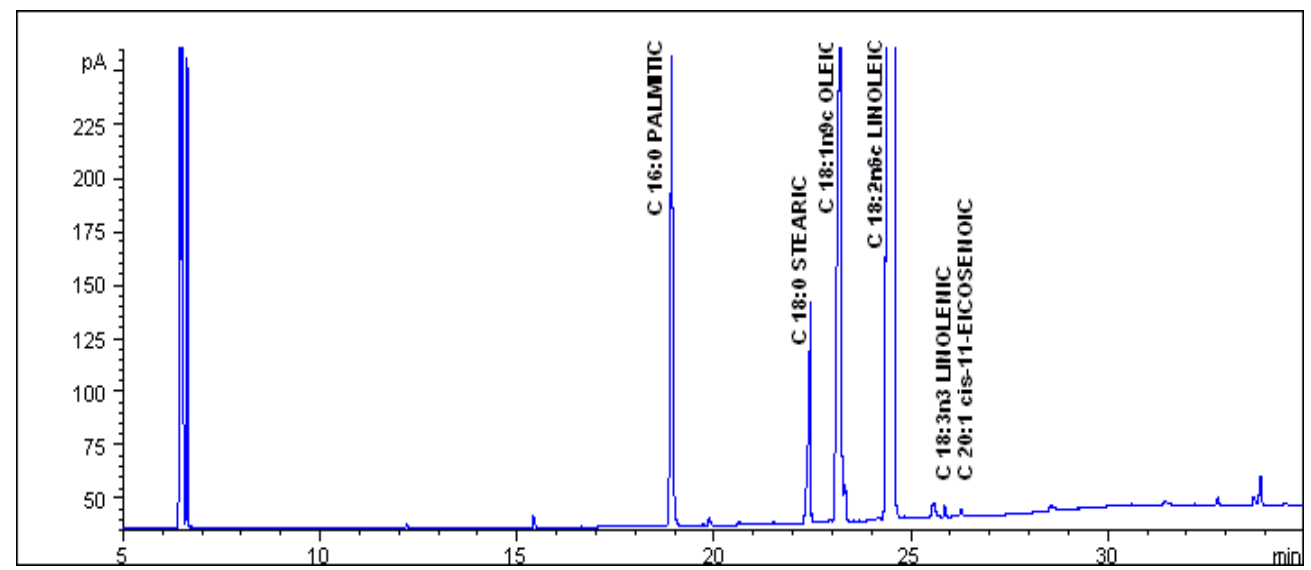

Figure 2. Gas-liquid chromatogram of fatty acid methyl esters of oils from seed oils Cartamus lanatus (L.) Boiss.

$(3.5 \%)$ acids. In the total amount of fatty acids, palmitoleic, linolenic, eicocenic and myristic acids accounted only in the least amount $0.1 \%$ each of the total.

The observed values in the seed of $C$. lanatus are very similar to those of grape seed and poppy oils, the linoleic acid content of which is $72.19-75.02$ and $72.55 \%$; oleic acid is $14.8-17.34$ and $13.30-17.80 \%$; palmitic acid is 9.72-10.22 and 7.96-10.19\% [Rahim et al., 2011; Fernanda et al., 2018]. The content of linoleic acid in the seeds of the studied species is even higher than in soybean (53.8\%) and sunflower (55\%) oils, which are widely used in the food industry, cooking, medicine, pharmaceuticals, cosmetics, as well as the production of paint and varnish materials and soap [Petibskaya, 2012; Kurkin et al., 2017].

The properties of vegetable fatty oils are determined mainly by composition and content of higher fatty acids that enter the human body only with food consumption [Mitova et al., 2003]. It is known that oil rich in linoleic acid plays a regulatory role in diseases of the cardiovascular system, atherosclerosis, hypertension, promotes the formation of a number of metabolic regu- lators and the structure of the plasma membrane [Viles et al., 1989]. Linoleic acid also has protective properties, and it is a necessary component in the synthesis of ceramides, a key group of compounds that make up the skin lipid barrier, inhibiting UV induced hyperpigmentation [Murthy et al., 2008]. Oleic acid is important in the metabolism in the human body, performs energy and plastic functions, strengthens the immune system, and reduces cholesterol. With a lack of this acid in the body, the permeability of cell membranes changes dramatically, which can lead to their weakening. The high content of linoleic oil in the studied oil and a significant content of oleic acids, which are $\omega-6$ and $\omega-3$ unlimiting fatty acids, from a dietary point of view characterizes seed oil of $C$. lanatus as a valuable product. To determine the scope of application of vegetable oil, it is also very important to define its physicochemical and organoleptic characteristics, which are very valuable for the standardization of oil. The results of analyzes of physicochemical and organoleptic characteristics of the oil are presented in Table.

The results of the conducted analysis showed that

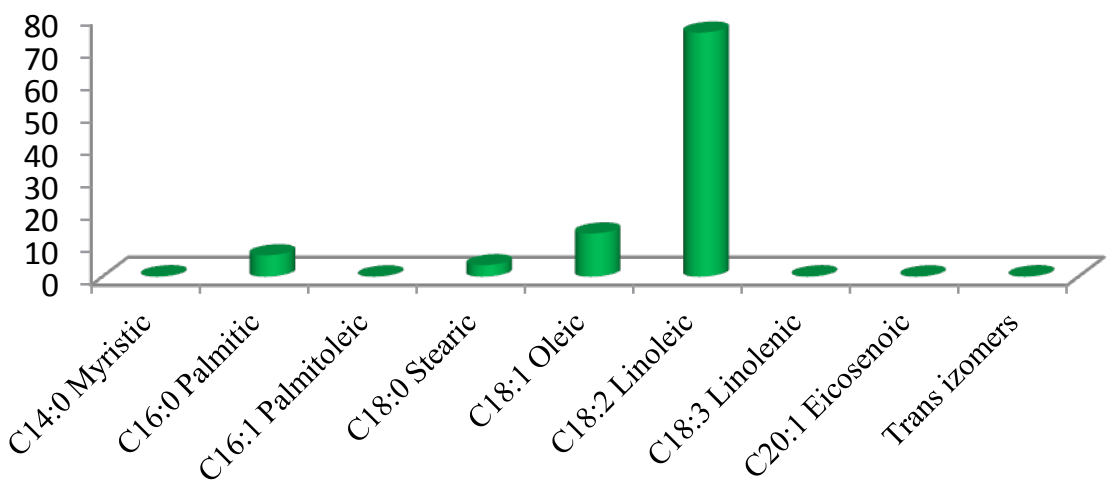

Figure 3. Fatty acid content in Cartamus lanatus (L.) Boiss oil (\%). 
Table. Physicochemical characterization of fatty oil obtained from the seeds of Cartamus lanatus (L.) Boiss. plants.

\begin{tabular}{|c|c|c|c|c|}
\hline № & $\begin{array}{c}\text { The name of the } \\
\text { experiment }\end{array}$ & $\begin{array}{c}\text { Unit of } \\
\text { measurement }\end{array}$ & Test method & Result \\
\hline 1. & $\begin{array}{l}\text { Organoleptic } \\
\text { indicators }\end{array}$ & & GOST 5472-50 & $\begin{array}{l}\text { seed oil is a bright yellow clear } \\
\text { liquid with a pleasant taste }\end{array}$ \\
\hline 2. & $\begin{array}{l}\text { Free fatty acids (such } \\
\text { as oleic acid) }\end{array}$ & $(\%)$ & GOST R 50457-92 & 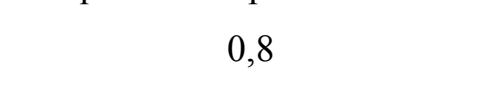 \\
\hline 3. & Peroxide value & $\mathrm{mmol} \mathrm{O}_{2} / \mathrm{kg}$ & GOST R 51487-99 & 2,1 \\
\hline 4. & Color (Lovibond) & Red / Yellow & GOST 5477-2015 & 0,6 Red, 6 yellow \\
\hline 5. & Iodine number & İV & GOST 5475-69 & 142,5 \\
\hline 6. & $\begin{array}{c}\text { Saponification } \\
\text { number }\end{array}$ & $\mathrm{KOH}$ & GOST 5478-2014 & 192,1 \\
\hline 7. & $\begin{array}{c}\text { Mass fraction of } \\
\text { phosphorus- } \\
\text { containing substances }\end{array}$ & $\mathrm{mg} / \mathrm{kg}$ & $\begin{array}{l}\text { GOST R 52676- } \\
2006\end{array}$ & 3,0 \\
\hline
\end{tabular}

the fatty oil obtained from the seeds of C. lanatus has a saponification number of 192.1. Free fatty acids in oil are formed as a result of the hydrolysis of triglycerides. For $C$. lanatus, the amount of free fatty acids is $0.8 \%$, the amount of peroxide $-2,1 \mathrm{mmol} \mathrm{O}_{2} / \mathrm{kg}$, the iodine number is 142.5 , and phosphorus-containing substances, the weight fraction is $3.0 \mathrm{mg} / \mathrm{kg}$.

Our data on the content, component composition and physicochemical parameters of the fatty seed oil of $C$. lanatus differ to some extent from those obtained by A.A. Kuliyev [1983], E.A. Weiss [1983], I.Y.L. Murthy and N.K. Anjani [2008]. The revealed difference in the quantitative content of the main components of fatty oil might be related to the different soil-climatic and ecobiological conditions of growth of plants $C$. lanatus. Further investigations should be performed to dissect the importance of soil composition and ecobiological conditions in the fatty acid content of $C$. lanatus.

\section{CONCLUSION}

The high amount of fatty acid of $C$. lanatus collected in several areas of Azerbaijan are comparable to that of just recognized valuable oil seeds such as grape and poppy. Thus our data demonstrate the value of the oil extracted from $C$. lanatus seeds. Taking into account the large natural reserves in the flora of Azerbaijan, it can be confirmed that $C$. lanatus has quite good prospects for use as a medicinal, food and technical plant.

\section{REFERENCES}

El-Shaer N., Shaaban E., Abou-Karam M., El-Din A. (1998) Flavonoids from Carthamus lanatus.

J. Pharm. Sci., 12: 23-26.

Felicano A., Medarde M., Del Rey B., Del Corral J.,
Barrero A. (1990a) Bisabolane related glycosides from Carthamus lanatus. Phytochemistry. 29(2): 645-648.

Felicano A., Medarde M., Del Rey B., Del Corral J., Barrero A. (1990b) Eudesmane glycosides from Carthamus lanatus. Phytochemistry, 29(10): 32073211.

Fernanda B., Fernanda C., Elias A., Eduardo P., Jorge M. (2018) Chemical composition of cold pressed Brazilian grape seed oil. J. Food Sci. Technol, Campinas., 38(1): 164-171.

Flora Azerbaidjana ( 1961) Baku: AN Azerb. SSR, 8: 479-480 (in Russian)

Harborne J.B., Baxter H., Mass G.P. (1999) Phytochemical dictionary. A handbook of bioactive compounds from plants. Taylor \& Francis Ltd.: London, $469 \mathrm{p}$.

Heller D. (1986) Personal communication from the Dept. of Botany, Institute of Life Sciences, Hebrew University of Jerusalem, Israel, $7 \mathrm{p}$.

Kim D., Kim S., Park S., Han M. (1999) Metabolism of quercitrin by human intestinal bacteria and its relaltion to some biological activities. Biol. Pharm. Bull., 22: 749-751.

Kuliyev A.A. (1983) Biologicheskoye i fitokhimicheskoye issledovaniye vidov roda Saflor (Carthamus L.), proizrastayushich $\mathrm{v}$ Nakhchevanckoy ASSR. Avtoref. dis. kand. biol. nauk. Baku, 1983, 22 s (in Russian)

Kurkin V.A., Rosikhin D.V., Ryazanov T.K. (2017) Sravnitelnoye issledovanie sostava zhirnix kislot, rastoropshi i podsolnechnoqo masla. Medisinskiy almanax, 1(46): 99-102 (in Russian)

Lahloub M., Amor M., El-Khajaat S., Haraz F. (1993) 
A new serotonin derivative from seeds of Carthamus lanatus L. J. Pharm. Sci. 9: 234-243.

Lee J.Y., Chang E.J., Kim H.J., Park J.H., Choi S.W. (2002) Antioxidative flavonoids from leaves of Carthamus tinctorius. Arch. Pharm. Res., 25: 313319.

Mitova M., Taskova R., Popov S., Berger R.G., Krings U., and Handjieva N. (2003) GC/MS analysis of some bioactive constituents from Carthamus lanatus L. Zeitschrift für Naturforschung., 58: 697703.

Morishita H., Ohnishi M. (2001) Absorption, metabolism and biological activities of chlorogenic acids and realated compounds, Studies in Natural Products Chemistry, 2: 919-953.

Murthy I.Y.L., Anjani N.K. (2008) Fatty acid composition in Carthamus species. Proceedings of the 7th international safflower conference. Wagga, New South Wales, Australia, pp. 1-6.

Novruzov E. and Shamsizade L. (1998) Anthocyans of Carthamus species. Chem Nat Compd. 34: 514515.

Oomah B.D., Liang J., Godfrey D., Mazza G. (1998) Microwave heating of grapeseed: effect on oil quality. J. Agric. Food Chem., 46(10): 4017-4021.

Pathak D., Pathak K., Singla A.K. (1991) Flavonoids as medicinal agents precent advances. Fitoterapia., 62: 371-389.

Petibskaya V.S. (2012) Soya: Khimicheskiy sostav i ispolzovanie. Pod redaktsiyey akademika Rossiyskoy akademii selskoxozyaystvennix nauk.V.M. Lukomtsa. - Maykop: Polygraph-YUG OJSC, 432 pp (in Russian)

Rahim A., Kiralan M., Arslan N., Bayrak A., Doğramac1 S. (2011) Variation in fatty acid composition of registered poppy (Papaver sumniferum L.) Seed in Turkey. Akademik Gida, 9(3): 22-25.

Sani F., Jawad A. (2016) Preliminary phytochemical analysis, antioxidant and antimicrobial evalution of Carthamus lanatus. Innovare Journal of Sciences. 4(5): 1-3.

Taskova R., Mitova M., Najdenski H., Tzvetkova I., Duddeck H. (2002) Antimicrobial activity and cytotoxicity of Carthamus lanatus. Fitoterapia., 73: 540-543.

Viles R.O., Gottenbos J.J., Robblen G., Downey R. K. (1989) Nutritional characteristics and food uses of vegetable oils. In Oil crops of the world: Mc. Graw Hill, New York, USA, 36 p.

Wassel G., Saeed A., Ibrahim N., El-Eraqy W. (1996)
Flavonoids of Nelumbo nucifera Gaertn and biological evaluation. Egypt. J. Pharm. Sci. 37: 585-596.

Weiss E.A. (1983) Oilseed Crops. Chapter 6. Safflower. Longman Group Limited, Longman House: London, UK., pp. 216-281.

\section{Carthamus lanatus (L.) Boiss. bitkisinin toxumundan alınan piy yağının kimyəvi tərkibinin öyrənilməsi}

\section{Şəhla Ә. Qasımova}

AMEA Botanika Institutu, Badamdar 40, Bakı AZ1004, Azərbaycan

Məqalədə Carthamus lanatus (L.) Boiss. (Asteraceae Bercht. et J.Preslu) bitkisinin toxumunun piy yağının fiziki-kimyəvi xüsusiyyətləri, tərkibi və yağ turşularının miqdarı təqdim olunur. Bu növ Azərbaycanda arandan aşağ 1 dağ qurşağına kimi demək olar ki, bütün botanikicoğrafi rayonlarında yayılmışdır. Bitkinin toxumları Şamaxı rayonundan yı̆̆ılmışdır. Yağ turşularının metil efirlərinin keyfiyyət tərkibi və kəmiyyət göstəricisi "HP" 6890 alov ionlaşma detektoru ilə xromatoqrafda müəyyən edilmişdir, ayırmaq üçün Agilent 112-88A7 seriyalı kapilyar sütun istifadə edilmişdir. Qaz-maye xromatoqrafiya üsulu ilə $C$. lanatus bitkisinin toxumlarından alınan yağın tərkibində səkkiz yağ turşusu və trans-izomerlər müəyyən edilmişdir. Yağ turşularının əsas hissəsini linol $(75.2 \%)$ və olein turşuları (13.3\%) təşkil edir, qalan hissəsi isə palmitin $(6.6 \%)$, stearin $(3.5 \%)$, linolen $(0.1 \%)$, eykosin $(0.1 \%)$, palmitolein $(0.1)$, miristin $(0.1 \%)$ turşuları və trans-isomerlərdən $(0.14 \%)$ ibarətdir. Fiziki-kimyəvi analizlərə əsasən, piy yağının aşağıdakı göstəriciləri var: sabunlaşma ədədi 192.1, sərbəst yağ turşularının miqdar1 $0.8 \%$, peroksid ədədi 2.1 , yod ədədi 142.5 , fosfor tərkibli maddələrin kütləsi - $3.0 \mathrm{mq} / \mathrm{kq}$. Yağın tərkibində yüksək miqdarda $\omega-6$ və $\omega-3$ doymamış yağ turşuları olan linol vo olein turşuların olması $C$. lanatus bitkisinin toxumlarını qiymətli bir məhsul kimi xarakterizə edir. Azərbaycan florasında C. lanatus bitkisinin böyük təbii ehtiyatlarının olması nəzərə alınarsa, bu növün dərman, qida və texniki bitki kimi istifadəsi üçün olduqca yaxşı perspektivləri olduğu iddia edilə bilər.

Açar sözlor: Asteraceae, piy yağll bitki, qaz-maye xromatoqrafiya, yağ turşuları. 


\section{PLANT \& FUNGAL RESEARCH}

\section{Изучение химического состава жирного масла из семян Carthamus lanatus (1.) Boiss.}

\section{Шахла А. Гасымова}

Институт ботаники НАНА, Бадамдар 40, Баку AZ1004, Азербайджан

В статье приводятся физико-химические свойства, состав и содержание жирных кислот масла семян Carthamus lanatus (L.) Boiss. (сем. Asteraceae Bercht. Et J. Presl). Данный вид распространен от низменности до нижнего горного пояса почти во всех ботанико-географических районах Азербайджана. Семена растения были заготовлены в Шемахинском районе. Качественный состав и количественное определение метиловых эфиров жирных кислот определены на хроматографе серии «НР» 6890, для разделения использовали капиллярную колонку Agilent 112-88А7 с пламенно-ионизационным детектором. Методом газожидкостной хроматографии в составе жирного масла из семян C. lanatus установлено 8 жирных кислот и трансизомеры. Основную часть жирных кислот составляют линолевая (7.2\%) и олеиновая кислоты (13.3\%). Остальная часть жирных кислот приходится на долю пальмитиновой (6.6\%), стеариновой $(3.5 \%)$, линоленовой $(0.1 \%)$, эйкозиновой $(0.1 \%)$, пальмитолеиновой $(0.1)$, миристиновой $(0.1 \%)$ кислот и трансизомеры $(0.14 \%)$. На основании физико-химических анализов установлено, что жирное масло имеет следующие показатели: число омыления - 192.1, количество свободных жирных кислот $-0.8 \%$, пероксидное число -2.1 , йодное число - 142.5, весовая доля фосфорсодержащих веществ - 3.0 мг/кг. Высокое содержание в исследуемом масле линолевой и значительное содержание олеиновой кислот, являющихся $\omega-6$ и $\omega-3$ непредельными жирными кислотами с диетической точки зрения характеризует масло семян C. lanatus как ценный продукт. Учитывая большие природные запасы C. lanatus во флоре Азербайджана можно утверждать, что вид имеет достаточно хорошие перспективы использования в качестве лекарственного, пищевого и технического растения.

Ключевые слова: Asteraceae, жирномасличное растение, газожидкостная хроматография, жирные кислоты. 